\title{
The relationship between selected macroeconomic indicators and economic freedom in V4 countries
}

\author{
Monika Daňová \\ Faculty of Management \\ University of Prešov \\ Prešov, Slovakia \\ E-mail: monika.danova@unipo.sk \\ Slovakia \\ Elena Širá \\ Faculty of Management \\ University of Prešov \\ Prešov, Slovakia \\ E-mail: elena.sira@unipo.sk \\ Slovakia
}

\section{ABSTRACT}

The paper aims to determine the practical applicability of the indicator of economic freedom in economic policy. The problem areas that arose in connection with the given aim, had a significant influence on the determination of the goal of the work. We were interested in, whether a small degree of economic freedom is the cause of slow economic growth and development, or if the causal link going in the opposite direction? Is the relationship between these elements and economic freedom the same always and everywhere? To answer these questions, we perform a series of analyzes on the data panel of the V4 countries for the period 2000-2019. Based on the obtained results, we identify those factors whose development is strongly related to the development of economic freedom. The results suggest that economic freedom is strongly correlated with public debt, exports, and the level of unemployment, is reflected in the values of these elements and at the same time is significantly affected by these elements. The strength and nature of their relationship with economic freedom vary across the group. Therefore, they cannot be considered as indicators of the state of economic freedom. Contrary to some published findings, little evidence has been obtained that economic freedom significantly affects economic growth.

\section{Keywords: Economic Growth, Development of Social System, Economic Freedom, Determinants of Economic Freedom, V4 Countries}

\section{INTRODUCTION}

The lack of economic growth in many countries is one of the most important economic problems in historical and contemporary terms. But why are some countries experiencing high levels of economic growth while others are not, and what are the causes of economic growth? These are complex issues that have attracted widespread attention [6], [2], [26] and many others) since the time of Aristotle. Some authors emphasize the need for economic freedom because they see it as a prerequisite for economic growth [14], [15]. Others consider it a sign of the country's maturity and thus an accompanying phenomenon in the development of the social system. Alternatively, they allow for a two-way relationship, tending to look for a positive link between the degree of economic freedom and economic growth.

Despite a large number of studies, many problems remain unresolved. Recent studies have highlighted four issues in the study of the relationship between freedom and growth. First, the direction of causality is not clear. Does this mean that economic freedom causes economic growth or does economic growth affect economic freedom? Second, does economic freedom affect the development of the system directly or indirectly through the determinants of economic growth? Third, economic freedom is often measured by broad composite indices containing a large number of variables. That is why it is difficult to say exactly what creates economic freedom. Naturally, with such an intention, it is difficult to identify whether all components of economic freedom affect growth in the same direction.

The purpose of this paper is to examine the direction and strength of the interaction between economic freedom, economic growth, and some of its determinants, and to try to identify factors that are generally positively correlated with economic freedom.

\section{THE CONCEPT OF ECONOMIC FREEDOM}

Economic freedom is a construct, that tries to express the extent to which the economy is driven by a market economy, respectively what are the possibilities of concluding voluntary contracts within a stable and predictable rule of law that respects the treaties and protects private property with a 


\section{(C) Center for Promoting Education and Research (CPER) USA}

www.cpernet.org

limited degree of interventionism in the form of government property, regulations and taxes [22].

Several methodologies have been developed to measure the degree of economic freedom. From the point of view of the possibility of monitoring long-term development, annual monitoring, carried out in parallel by the Fraser Institute and the Heritage Foundation is important.

According to The Heritage Foundation's methodology, economic freedom is assessed in four areas. Every mentioned area is assessed with several indicators, that identify the occurrence of 12 freedoms: the rule of law (protection of property rights and anti-corruption), government restrictions (fiscal freedom and size of government spending), performance regulators (trade, labor, and monetary freedom), market openness (freedom of enterprise, investment, and financial freedom). Each of them is considered equally important in the overall assessment. By averaging their value, the obtained score is the basis for the classification of economic freedom in the country at one of 5 levels (free - mostly free - on average free - mostly non-free - non-free).

A similar approach to the definition of economic freedom is applied in the methodology of the Fraser Institute. Its authors cite the right to choose, the competitiveness of markets, the existence and availability of competitive markets, and the protection of the rights and property of individuals as key components of economic freedom. Based on this idea, the size of state expenditures, taxes and investments, the structure of the legal system and securing property rights, a noninflationary environment are identified as key areas for economic freedom; freedom to trade on international markets, regulation of the credit market, labor markets, and business, and finally a regulatory framework. In these five areas, 24 components comprising a total of 42 variables are assessed directly or approximately annually. Evaluation within subindices is performed in an interval method. The achieved score depends on the degree of fulfillment of the assessed criterion. The subsequent overall assessment of a country's economic freedom is the result of equally significant partial assessments, using the quartile distribution of the assessed set of countries to be included in one of the degrees of economic freedom [24].

It should be noted that both methodologies have been used to assess economic freedom since the 1990s. During this period, there were minor changes in the selection of components and changes in the way their weights were assessed. However, this did not affect the overall assessment in a way, that would change the statement on the level of economic freedom [21], [24].

The total score of the indicator of economic freedom differs depending on the methodology used in countries, that are based on the values of the total score of the index evaluated as predominantly free, on average free, or mostly non-free. In the group of best-evaluated countries (overall evaluation min.
$85 \%$ of the maximum value), regardless of which of the methodologies is used, the overall evaluation is similar to identical [34].

The shift towards freer markets observed in the set of countries assessed in the period 1980-2016 is illustrated by the increased average rating of developed countries to 7.71 out of 6.43 and the average rating of developing countries increased to 6.65 out of 4.91 (assessed by the World Economic Freedom Index). Only one country, Venezuela, experienced any meaningful decline in the EFW index during this period [31]. A similar increase in economic freedom between 1995 and 2021 is quantified by the Heritage Foundation. As an example of the changes in the values of economic freedom as determined by the Heritage Foundation (Index of Economic Freedom) in the group of European countries from 57.5 to 70.6 (with a maximum value of 100).

\section{RELATIONS BETWEEN ECONOMIC FREEDOM AND GROWTH}

Economic freedom aims at various aspects the management and development of the socio-economic system. It measures a country's interaction with the world economy, such as financial liberalization, freedom of trade and investment, or the efficiency and integrity of government. More importantly, it also affects the possibilities of marketbased functioning of labor and financial markets [33].

Examining the nature of economic freedom, Nikolaev and Bennett [35] suggest, that when people have more control over their lives, they tend to strive better for passion and bring more success. Economic freedom theoretically improves a country's growth and prosperity by letting people decide their lives. Selfmanaged people can work alone or in a company and create goods and services that best meet the needs of the market [33]. Individuals are free to work, consume or invest in any channel that benefits them. This in turn increases market efficiency and economic growth. These studies emphasize that people's freedom to make decisions and manage their lives improves living standards, thereby boosting economic growth. This in turn allows people to work independently or in society and generate goods and services that meet the needs of the market [33]. If people have the freedom to work, consume or invest in any channel that benefits them, market efficiency and economic growth will increase.

However, this requires finding and respecting the optimal level of economic constraints and interventions in the market decisions of economic operators. Experience confirms that government action tends to rise above the minimum necessary level, through many restrictions on economic activities, that undermine people or personal freedom. In this way, the state reduces economic freedom.

The negative effects of restrictions on the free functioning of market mechanisms by the government can be observed at several levels; discussions are being held about the correct redirection of resources to certain activities (entities). Such a 
decision gives the entities (activities) concerned undeserved benefits [31]. Government support can undermine market efficiency by directing funds to inefficient projects of stateowned or private companies with strong politically linked relationships [9], [27]. Heckelman \& Knack [26] state, that political leaders can support state-owned enterprises and allocate financial resources from inefficient investment projects to private benefits. In addition, such a mechanism for acquiring resources reduces the need to strive for efficiency in their use or the effectiveness of their activities [32]. This suggests that greater economic freedom will theoretically reduce the government's influence on the economy, on the other hand, increase market efficiency and institutional quality, and lead to higher economic growth [17].

The impact of government restrictions on economic freedom is evident not only by influencing internal relations but also in the context of the openness of the economy to foreign input [36]. Dreher \& Gehring [16] cite the lower incidence of government restrictions and obstacles as a condition for stimulating economic growth by the inflow of foreign financial, physical, and human resources and the expansion of markets. Their effect was seen especially in emerging economies, where companies tend to lack financial resources, low technological and managerial experience. At the corporate level, acquiring them can improve a company's efficiency and profitability. At the national level, it will be reflected in higher values of macroeconomic aggregates, in the horizon of several periods in the increase and acceleration of economic growth.

On the other hand, in some cases, economic freedom may adversely affect the economic system. Sturm \& De Haan [39] believe, that the growth of domestic competition in an economically free environment, may cause companies with low efficiency and backward technologies to lag. Cali [9] point out, that economic freedom leads to greater interconnections between economies. This means an even higher risk for companies (economies). The absence of safeguard mechanisms in less competitive economies in such a case is detrimental, and a lack of state intervention can increase the economy's vulnerability to economic shocks and systemic risks [12]. Similarly, excessive economic freedom can be challenged based on the results of good policies often pursued by dictators [20]. Such opposite views on the relationship between the degree of government restraint and economic growth lead to the conclusion, that it is not possible to generalize when economic freedom is or is not an obstacle or condition to economic growth [29].

The positive, statistically, and economically significant relationship between EFW and development is well documented in Dawson [13], De Haan and Siermann [15], De Haan and Sturm [14], Gwartney et al. [23], and Weede [41]. These studies reveal a strong correlation between economic freedom, economic growth, and per capita income. However, given the design of the economic freedom indicator, it must be considered potentially endogenous, which makes it difficult to use it to predict economic growth. The unambiguous conclusion is also complicated by the possibility of two-way causality of the relationship [30]. It is possible to assume, that growth and high GDP per capita cause an institutional improvement measured by the indicator of economic freedom. This means, that richer countries can afford better institutions and reduced regulatory measures. On the other hand, practice shows, that the size of government is the result of growth, not the cause [19].

This is confirmed by several published findings. E.g. Using the dynamic methods of Granger causality, VegaGordillo and Alvarez-Arce [40] found, that economic freedom causes growth. However, they do not find a causal link between growth and economic freedom. Sturm and De Haan [14] show, that a change in economic freedom is strongly linked to growth. Carlsson and Lundstrom [10] also test the exogeny of economic freedom and reject the view, that economic freedom is endogenous in their analysis of the relationship between EFW and growth using the Hausman test. Gwartney et al. [23] use post hoc causality analysis, ergo propter hoc show, that increasing economic freedom leads to increased growth rates, while previous economic growth rates harm future changes in economic freedom.

This research assumes, that economic freedom is the key to prosperity; a high level of economic freedom stimulates economic development, while a low level causes stagnation and poverty. Similar to previous researches made by Hall and Jones [25], Acemoglu et al. [1], [3], Easterly and Levine [18], Rodrik et al. [38], La Porta et al. [28], Acemoglu and Johnson [1] we set, that the indicator of economic freedom, that was used in the study, is the index of economic freedom. We consider its structure to be suitable for assessing the presence of conditions and obstacles to economic activity and free decision-making by economic entities.

\section{DATA AND METHODS}

The study aims to determine the practical applicability of the indicator of economic freedom in economic policy. According to mentioned aim, we examine the relationship between economic freedom, expressed through an index indicator, economic growth, and some indicators of restrictions and preconditions for free decision-making by economic subjects.

The selection of independent variables is a synthesis of published findings on the direct and indirect relationship of these indicators to economic freedom. Razmi et al. [37] found that the overall economic freedom index correlates positively and strongly with economic growth, with trade openness being a statistically significant determinant. Barro [6], Razmi et al. [37] publish their studies about the negative impact of government consumption on economic growth and, consequently, on economic freedom. The inflation rate is 


\section{(C) Center for Promoting Education and Research (CPER) USA}

WwW.cpernet.org

added, because there are findings, that countries with a high degree of economic freedom are adopting structures, that lead to lower inflation; those with a high degree of political freedom do not adopt inflation-reducing institutional structures [5]. Attention to government expenditures is based on published findings, that countries with large governments have experienced above-average increases in the globalization index $\mathrm{KOF}$ and the index of economic freedom [7]. Finally, according to the critics of the indebtedness of economies, we assume the negative impact of government debt on the economic security of the social system. For this reason, longterm undesirable government debt was included in the set of assessed variables.

The examination of the interrelationship of variables is based on the use of correlation and regression analysis procedures to identify the presence, nature, and strength of the relationships of these variables to economic freedom. More precisely, to select indicators, that significantly restrict economic freedom.

To achieve the pre-marked goal, the analysis of the relationship is performed in several steps. The first step is to assess the dependencies between economic freedom and a set of macroeconomic indicators using correlation analysis procedures. The values of the Pearson correlation coefficient obtained for each pair of variables and each country separately are useful in classifying the existence and nature of dependence. A standard classification (e.g. [11]) is used to quantify the degree of dependence of the files thus formed.

To verify whether the observed correlations between quantities are not only apparent, the strength of the relationship is verified by regression analysis procedures. These procedures are applied in two steps: in the first step, the degree of impact is analyzed for each determinant individually:

$$
E F=f\left\{D_{i}\right\}
$$

Where EF- economic freedom index, Di-determinant from the set GDP growth rate, inflation, share of exports in GDP, tax burden, general government gross debt, and unemployment\}.

To define a complex of determinants that result in a certain level of economic freedom, the relationship is verified:

$$
E F=f\{g G D P ; E X P ; T R ; G D ; U E ; I N F\}
$$

Where gGDP- year-on-year GDP growth in\%, EXP- of GDP, GD - gross general government debt expressed as\% of GDP, UE - employment rate in\%, INF - percentage change in price levels.

This relationship was verified by regression analysis procedures on a linear regression model:

$E F_{t}=\alpha+\beta_{1} g H D P_{t}+\beta_{2} E X P_{t}+\beta_{3} T R_{t}+\beta_{4} G D_{t}+\beta_{5} U E_{t}+\beta_{6} I N F_{t}+\varepsilon_{t}$ (3)

The second part of the relationship study is to verify the impact of economic freedom on economic growth. Based on the published findings, we assume, that the activity of the subjects of the economic system and its development are related to economic freedom, more precisely to a certain extent they are determined by its level. The strength of the impact of economic freedom on the following indicators is quantified in the study by regression analysis procedures on one-factor models:

$$
V_{i}=f\{E F\}
$$

Where Vi- variable from the set year-on-year GDP growth in $\%$, the share of exports in GDP in $\%$, tax burden expressed as $\%$ of GDP, gross general government debt expressed as\% of GDP, employment rate in\%, inflation; EF Index of Economic Freedom

The basis for the analysis is data from V4 countries, that describe the development of the evaluated phenomena in the period 2000 - 2019.

\section{RESULTS OF ANALYZES AND DISCUSSION}

Accepting the uniqueness of each of the economies, we performed all analyzes individually for each of the countries included in our study. We consider, that cooperation, common markets, or common activities and objectives do not preclude the specific conditions of each of the countries. However, the existence of these may be the cause of differences in the relationship between economic freedom, economic growth, and other determinants.

Due to the preferred focus of this study on the conditions of the Slovak economy, Table 1 shows the summary statistics of all variables for Slovakia. To illustrate the differences in the level of the evaluated variables compared to the other countries of the sample, the second part of the table shows the average values of the variables in the Czech Republic, Hungary, and Poland, as well as the average level of the indicator in the EU Community. share of exports in GDP in $\%$, TR - tax burden expressed as\%

Table 1 Differences in the values of the variables analyzed in the study in the V4 countries

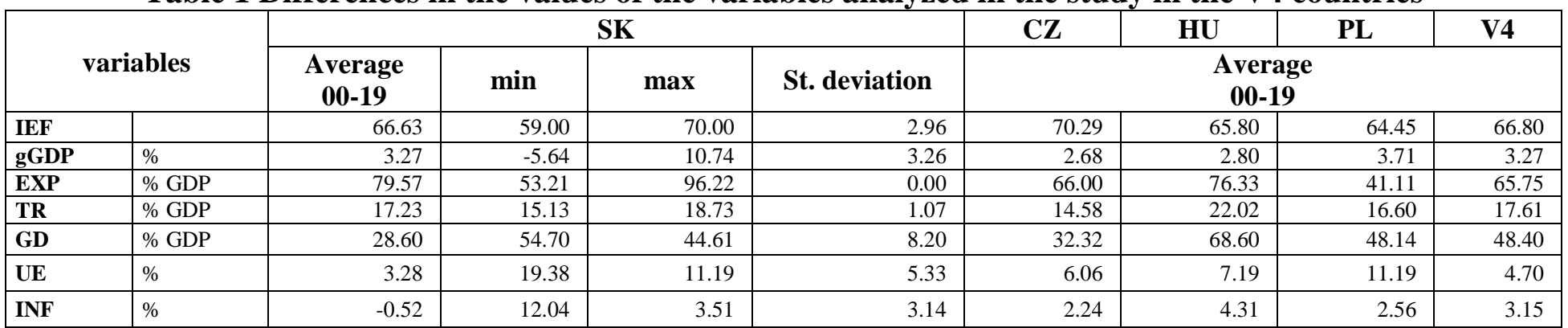


Legend: gGDP- year-on-year GDP growth in\%, EXP - against the variables export (as\% of GDP) and unemployment. share of exports in GDP in\%, TR- tax burden expressed as\% of This confirms the correctness of our assumption of the national GDP, GD- gross general government debt expressed as $\%$ of specifics of the relationship.

GDP, UE- unemployment rate in\%, INF- percentage change price level

Source: author, according to Heritage Foundation, Eurostat, and WorldBank, 2021

We further verified the mutual correlations of the variables. The corresponding coefficients are given in the cells of Table 2, statistically, significant correlations at the $5 \%$ level of significance are color-coded in the cells of the table. While in Slovak conditions only the variable public debt $(-0.6743)$ is statistically significantly correlated with economic freedom, in other countries such a nature of the relationship was also found
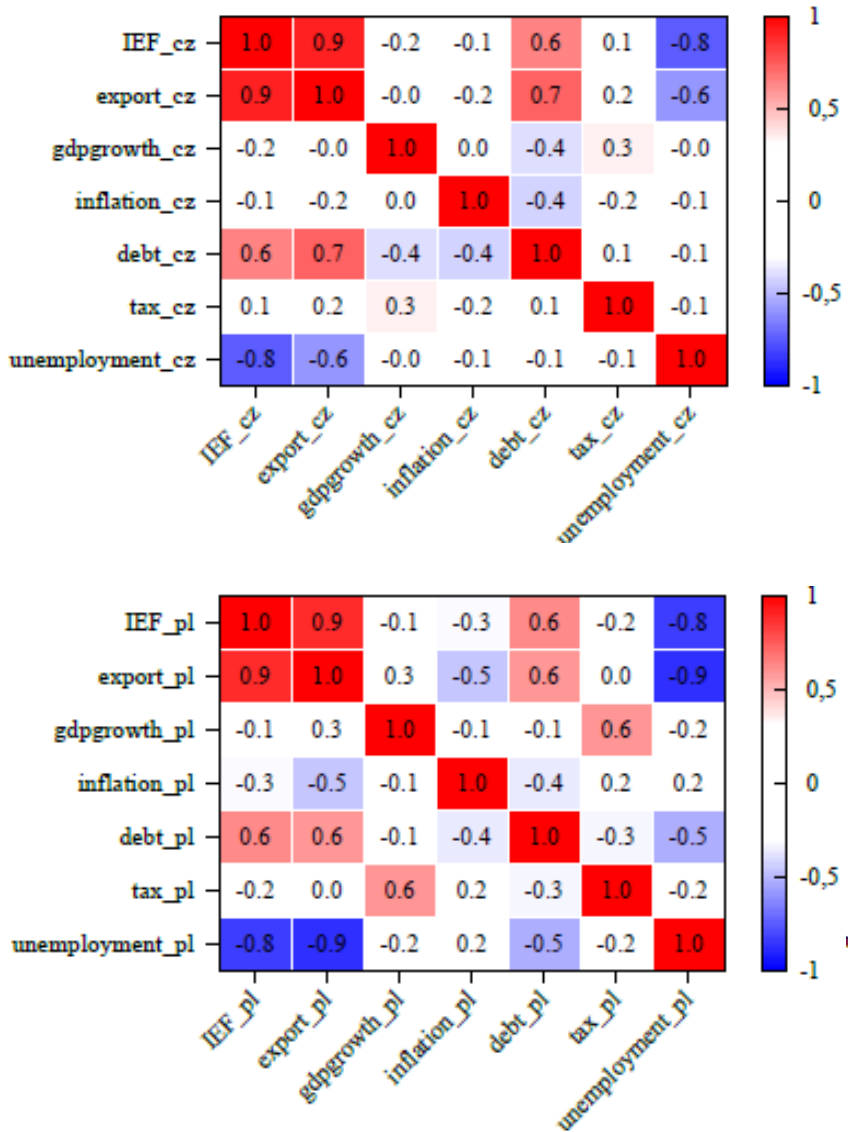

Figure 1 Correlations between variables

Note: Statistically significant correlations at the 5\% level of significance are found in shaded cells Source: author, according to Heritage Foundation, Eurostat, and World Bank, 2021

The finding on the nature of the relationship in the Slovak Republic is different, wherefrom the whole set of analyzed determinants, only the weakening effect of the growing public debt on economic freedom was confirmed by regression analysis (Table 2). The answer to this contradictory

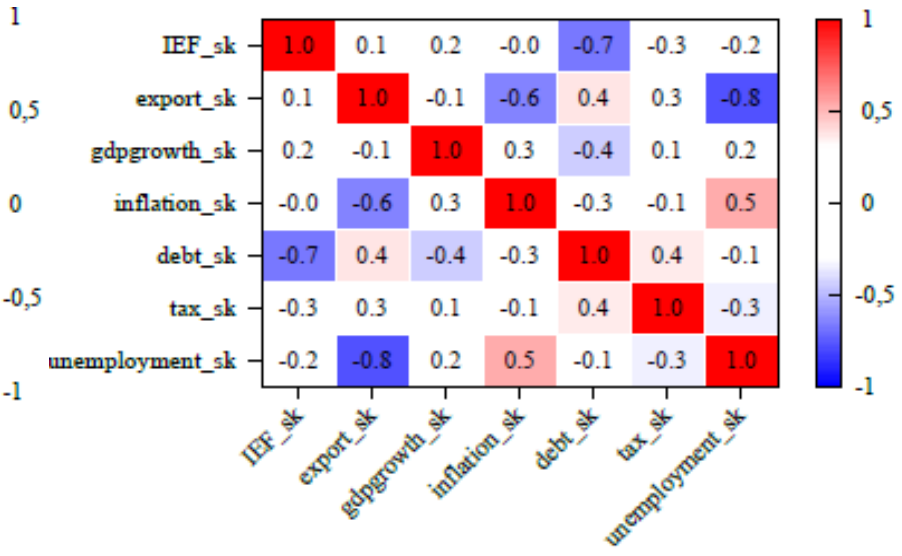

The analysis of the relationships verified by regression analysis methods on one-factor models confirmed the small weight of each of the evaluated variables- in none of the examined economies did these variables appear as determinants, that could affect economic freedom. A statistically significant effect was repeatedly found for the variables export (as \% of GDP), public debt (in \% of GDP), and unemployment. Their effect varies across the file of analyzed countries. In the Czech Republic, Hungary and Poland, these variables have a positive effect on economic freedom with varying degrees of influence across a set of factors and a set of countries.

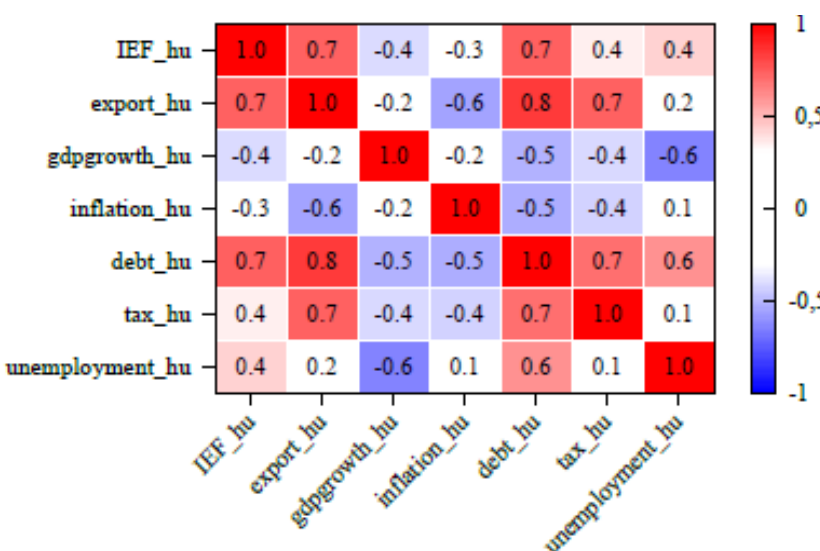

finding turns out to be considerations about the impact of public debt on solvency and liquidity [4]. If the present value of available resources is higher than the total amount of debt obligations, the relatively high share of public debt in GDP does not reduce the assumptions of economic growth and economic freedom. On the other hand, there is the solvency problem, that countries face when their total liabilities exceed their ability to pay at any time. 
Table 2 Quantification of individual fixed effects of variables on economic freedom in V4 countries

\begin{tabular}{|c|l|c|c|c|c|c|}
\hline Country & Variables & $\boldsymbol{\beta i}$ & t-statistics & \multicolumn{2}{|c|}{ p-value } & $\mathbf{R}^{\mathbf{2}}$ \\
\hline \multirow{5}{*}{ CZ } & gGDP & -0.269 & -1.035 & 0.315 & & 0.059 \\
\cline { 2 - 7 } & EXP & 0.233 & 9.723 & 0.000 & $* * *$ & 0.840 \\
\cline { 2 - 7 } & TR & 0.610 & 0.413 & 0.685 & & 0.009 \\
\cline { 2 - 7 } & GD & 0.286 & 3.931 & 0.001 & $* * *$ & 0.462 \\
\cline { 2 - 7 } & INF & -0.412 & -0.887 & 0.387 & $* * *$ & 0.042 \\
\cline { 2 - 7 } & UE & -1.186 & -5.180 & 0.000 & $* * *$ & 0.598 \\
\hline \multirow{5}{*}{ HU } & gGDP & -0.207 & -1.825 & 0.086 & $*$ & 0.164 \\
\cline { 2 - 7 } & EXP & 0.100 & 4.765 & 0.000 & $* * *$ & 0.558 \\
\cline { 2 - 7 } & TR & 0.405 & 1.474 & 0.158 & & 0.108 \\
\cline { 2 - 7 } & GD & 0.120 & 4.834 & 0.000 & $* * *$ & 0.565 \\
\cline { 2 - 7 } & INF & -0.190 & -1.635 & 0.119 & $* * *$ & 0.129 \\
\cline { 2 - 7 } & UE & 0.262 & 2.028 & 0.058 & $*$ & 0.186 \\
\hline \multirow{5}{*}{ PL } & gGDP & -0.265 & -0.449 & 0.659 & & 0.012 \\
\cline { 2 - 7 } & EXP & 0.360 & 5.904 & 0.000 & $* * *$ & 0.659 \\
\cline { 2 - 7 } & TR & -1.073 & -0.900 & 0.380 & & 0.043 \\
\cline { 2 - 7 } & GD & 0.382 & 2.610 & 0.018 & $* *$ & 0.275 \\
\cline { 2 - 7 } & INF & -0.330 & -0.846 & 0.409 & & 0.038 \\
\cline { 2 - 7 } & UE & -0.593 & -5.763 & 0.000 & $* * *$ & 0.649 \\
\hline \multirow{5}{*}{ SK } & gGDP & 0.133 & 0.707 & 0.489 & & 0.029 \\
\cline { 2 - 7 } & EXP & 0.073 & 1.557 & 0.137 & & 0.119 \\
\cline { 2 - 7 } & TR & -1.023 & -1.736 & 0.100 & $*$ & 0.143 \\
\cline { 2 - 7 } & GD & -0.235 & -3.636 & 0.002 & $* * *$ & 0.423 \\
\cline { 2 - 7 } & INF & -0.328 & -1.580 & 0.132 & & 0.122 \\
\cline { 2 - 7 } & UE & -0.231 & -1.393 & 0.181 & & 0.097 \\
\hline
\end{tabular}

Legend: gGDP- year-on-year GDP growth in\%. EXP - Similarly, as a result of the multifactorial economic freedom share of exports in GDP in \%, TR - tax burden expressed as \% indicator, the impact of inflation appears to be insignificant. of GDP, GD- gross general government debt expressed as \% of GDP, UE- unemployment rate in\%, INF- percentage change price level

As the standard phenomenon of economic reality is the influence of the mutual relation of two phenomena by the action of a set of other co-occurring phenomena in the next

Source: author, according to Heritage Foundation, Eurostat, and World Bank, 2021

In some cases, lower values of the coefficient of determination signal the existence of a concurrent influence of other variables and only the proportion of specific determinants in the resulting value of economic freedom. According to the findings of Brkić [8], this value is almost evenly distributed in the values of partial freedoms in EU countries. Their significance could therefore be monitored step, the degree of possible negotiation or additive influence was determined on a model including all considered variables. Multiple regression analysis procedures excluded those from the model for which no statistically significant effect was found. The results of the performed analysis are shown in Table 3. By comparing the findings in it with the findings of previous analyzes, the volatility of the relationship depending on the specific conditions of a particular country was rather at the level of the sub-indices of the EF index [14].

Table 3 Quantification of the fixed effects of the set of variables on economic freedom in the V4 countries

\begin{tabular}{|c|c|c|c|c|c|c|c|c|}
\hline \multirow{2}{*}{ Country } & \multirow{2}{*}{ Constant } & \multicolumn{5}{|c|}{ Regression coefficient for the variable } & \multirow{2}{*}{$\mathbf{R}^{2}$} & \multirow{2}{*}{ p-value } \\
\hline & & EXP & $\begin{array}{l}\text { gGDP } \\
\end{array}$ & GD & TR & UE & & \\
\hline $\mathbf{C Z}$ & 61.885 & 0.184 & -0.265 & - & - & -0.514 & 0.954 & $* * *$ \\
\hline HU & 71.772 & 0.138 & -0.200 & - & -0.792 & - & 0.779 & $* *$ \\
\hline PL & 75.874 & 0.259 & -0.601 & - & -0.977 & -0.350 & 0.934 & $* *$ \\
\hline SK & 62.335 & 0.206 & -0.275 & -0.364 & - & 0.400 & 0.783 & $* *$ \\
\hline
\end{tabular}

Legend: gGDP - year-on-year GDP growth in \%, EXP- GDP, UE- the unemployment rate in \%, INF- percentage share of exports in GDP in \%, TR - tax burden expressed as \% change price level 
Source: author, according to Heritage Foundation, Eurostat, it, the analysis was subjected to a reversibly defined and WorldBank, 2021

Logically, the subject of interest is the answer to the relationship between the considered macroeconomic variables, the level of which is normally considered to be one of the question, to what extent the level of economic freedom can socio-economic objectives.

influence the development of the economic system. To obtain

Table 4 Quantification of fixed effects of economic freedom on some macroeconomic indicators in V4 countries

\begin{tabular}{|c|c|c|c|c|c|c|}
\hline Country & Variables & $\boldsymbol{\beta i}$ & t-statistics & & & $\mathbf{R}^{2}$ \\
\hline \multirow{6}{*}{$\mathrm{CZ}$} & gGDP & -0.221 & -1.035 & 0.315 & & 0.059 \\
\hline & EXP & 3.607 & 9.723 & 0.000 & $* * *$ & 0.840 \\
\hline & TR & 0.015 & 0.413 & 0.685 & & 0.009 \\
\hline & GD & 1.617 & 3.931 & 0.001 & $* * *$ & 0.462 \\
\hline & INF & -0.102 & -0.887 & 0.387 & & 0.042 \\
\hline & UE & -0.505 & -5.180 & 0.000 & $* * *$ & 0.598 \\
\hline \multirow{6}{*}{ HU } & gGDP & -0.791 & -1.825 & 0.086 & * & 0.164 \\
\hline & EXP & 5.551 & -3.769 & 0.001 & $* * *$ & 0.558 \\
\hline & TR & 5.551 & 4.765 & 0.000 & $* * *$ & 0.108 \\
\hline & GD & 4.719 & 4.834 & 0.000 & $* * *$ & 0.565 \\
\hline & INF & -0.682 & -1.635 & 0.119 & & 0.129 \\
\hline & UE & 0.710 & 2.028 & 0.058 & $*$ & 0.186 \\
\hline \multirow{6}{*}{ PL } & gGDP & -0.044 & -0.449 & 0.659 & & 0.012 \\
\hline & EXP & 1.832 & 5.904 & 0.000 & $* * *$ & 0.659 \\
\hline & TR & -0.040 & -0.900 & 0.380 & & 0.043 \\
\hline & GD & 0.718 & 2.610 & 0.018 & $* *$ & 0.275 \\
\hline & INF & -0.116 & -0.846 & 0.409 & & 0.038 \\
\hline & UE & -1.093 & -5.763 & 0.000 & **** & 0.649 \\
\hline \multirow{6}{*}{ SK } & gGDP & 0.214 & 0.707 & 0.489 & & 0.029 \\
\hline & EXP & 1.620 & 1.557 & 0.137 & & 0.119 \\
\hline & TR & -0.138 & -1.736 & 0.100 & $*$ & 0.143 \\
\hline & GD & -1.805 & -3.636 & 0.002 & $* * *$ & 0.423 \\
\hline & INF & -0.371 & -1.580 & 0.132 & & 0.122 \\
\hline & UE & -0.422 & -1.393 & 0.181 & & 0.097 \\
\hline
\end{tabular}

Legend: gGDP- year-on-year GDP growth in\%, EXPshare of exports in GDP in\%, TR- tax burden expressed as \% of GDP, GD- gross general government debt expressed as \% of GDP, UE- the unemployment rate in \%, INF- percentage change price level

Source: author, according to Heritage Foundation, Eurostat, and WorldBank, 2021

The results obtained by the regression analysis procedures (Table 4) indicate two facts: it is mainly the bidirectionality of the relationship in the case of those variables, where a significant correlation of phenomena was found by correlation analysis. The second finding is based on a comparison of the values of regression coefficients, which signals a more significant impact of economic freedom on indicators of performance, development, and functioning of markets compared to the findings of their impact on economic freedom.

\section{CONCLUSION}

The undisputed importance of economic freedom is confirmed by many theoretical and empirical analyzes. Their conclusions are influenced by the degree of economic and social development as well as the degree of economic freedom in the countries under consideration.

We aimed to find out. whether the indicator of economic freedom is usable in practical economic policy. The subject of the analyzes was the relationship of economic freedom to a set of macroeconomic indicators. Their results revealed a relatively weak relationship and across countries of the set a different relationship to the set of selected independent variables. Using linear regression in all V4 countries as well as for the EU as a whole, the dependence of economic freedom on GDP or inflation was not found. In the Czech Republic, Hungary, and Poland, economic freedom correlates linearly with public debt, and public debt is also rising with the rising value of the index. The tax burden and inflation are not linearly related to the economic freedom index. It can therefore be stated, that the indicator generally not used to predict the future development of economic freedom was found, which confirms our belief in the limited practical applicability of the 


\section{(C) Center for Promoting Education and Research (CPER) USA}

www.cpernet.org

economic freedom indicator: the indicator is useful in predicting the future development of key macroeconomic indicators, the rate in predicting social and economic development in the short term monitored by the economic growth indicator. According to the findings of the analyzes performed, the variability of subindex values and the overall score of the economic freedom index have a significant effect on the possibility of identifying the mutual relationship of the economic freedom indicator with indicators, that characterize resource sufficiency, public sector size, autonomy and stability of the economic system.

\section{REFERENCES}

Acemoglu, D. \& Johnson, S. (2005). Unbundling institutions. Journal of political Economy, 113(5), 949-995.

Acemoglu, D., Johnson, S. \& Robinson, J. A. (2001). The colonial origins of comparative development: An empirical investigation. American economic review, 91(5), 1369-1401.

Acemoglu, D. (2002). Technical change, inequality, and the labor market. Journal of economic literature, 40(1), 7-72.

Agénor, P. R. \& Montiel, P.J, 1996. Development Macroeconomics, Princeton University Press, Princeton.

Banaian, K. \& Luksetich, W. A. (2001). Central bank independence, economic freedom, and inflation rates. Economic Inquiry, 39(1), 149-161.

Barro, R. J. (1991). Economic growth in a cross section of countries. The quarterly journal of economics, 106(2), 407-443.

Bergh, A., Karlsson, M. Government size and growth: Accounting for economic freedom and globalization. Public Choice 142, 195-213 (2010). https://doi.org/10.1007/s11127-009-9484-1

Brkić, J. (2020). The relationship between economic freedom and economic growth in eu countries. https://www.tdx.cat/bitstream/handle/10803/669302/2020_Tesis_\%20Brkic_Ivana.pdf?sequence=1\&isAllowed=y

Cali, M. \& Te Velde, D. W. (2011). Does aid for trade really improve trade performance? World development, 39(5), 725-740.

Carlsson, F. \& Lundström, S. (2002). Economic freedom and growth: Decomposing the effects. Public choice, 112(3), 335-344.

Cohen, M. A. (1998). Monitoring and enforcement of environmental policy. Available at SSRN 120108.

Compton, R. A., Giedeman, D. C. \& Hoover, G. A. (2011). Panel evidence on economic freedom and growth in the United States. European Journal of Political Economy, 27(3), 423-435.

Dawson, J. W. (1998). Institutions, investment, and growth: New cross-country and panel data evidence. Economic inquiry, 36(4), 603-619.

De Haan, J. \& Sturm, J. E. (2000). On the relationship between economic freedom and economic growth. European journal of political economy, 16(2), 215-241.

De Haan, J. \& Siermann, C. L. (1998). Further evidence on the relationship between economic freedom and economic growth. Public choice, 95(3), 363-380.

Dreher, A. \& Gehring, K. (2012). Does aid buy (economic) freedom. Economic freedom of the world: 2012 annual report, 219-246.

Dutta, N. \& Williamson, C. R. (2016). Aiding economic freedom: Exploring the role of political institutions. European Journal of Political Economy, 45, 24-38.

Easterly, W., \& Levine, R. (2003). Tropics, germs, and crops: how endowments influence economic development. Journal of monetary economics, 50(1), 3-39.

Faria, H. J., \& Montesinos, H. M. (2009). Does economic freedom cause prosperity? An IV approach. Public Choice, 141(1), 103-127.

Glaeser, E. L., La Porta, R., Lopez-de-Silanes, F., \& Shleifer, A. (2004). Do institutions cause growth? Journal of economic Growth, 9(3), 271-303.

Gwartney, J., \& Lawson, R. (2006). Economic freedom of the world. Annual report, Fraser Institute.

Gwartney, J. D., \& Holcombe, R. G. (2019). Economic Freedom, Constitutional Structure, and Growth in Developing Countries. In Institutions and Collective Choice in Developing Countries (pp. 33-60). Routledge. 
Gwartney, J. D., Holcombe, R. G., \& Lawson, R. A. (2004). Economic freedom, institutional quality, and cross-country differences in income and growth. Cato J., 24, 205.

Gwartney, J. D., Stroup, R. L., Sobel, R. S., \& Macpherson, D. A. (2021). Economics: private \& public choice. Cengage Learning.

Hall, R. E., \& Jones, C. I. (1997). Levels of economic activity across countries. The American Economic Review, 87(2), 173-177.

Heckelman, J. C., \& Knack, S. (2009). Aid, economic freedom, and growth. Contemporary Economic Policy, 27(1), 46-53.

Kenneth M.Kletzer \& Brian D. Wright(1998) "Soverign Debt as Intertemporal Barter, " Center for international and Development Economics Research, working papers C98-100.

La Porta, R., Lopez-de-Silanes, F., Pop-Eleches, C., \& Shleifer, A. (2004). Judicial checks and balances. Journal of Political Economy, 112(2), 445-470.

La Porta, R., \& Shleifer, A. (2008). The unofficial economy and economic development (No. w14520). National Bureau of Economic Research.

La Porta, R., Lopez-de-Silanes, F., Shleifer, A., \& Vishny, R. (1999). The quality of government. The Journal of Law, Economics, and Organization, 15(1), 222-279.

Lawson, K. N. \& Lawson, R. A. 2020. Economic Liberalizations Around the World Since 1970: Shock Therapy Versus Gradualism. Cato journal. 40(3).

Mandl, U., Dierx, A., Ilzkovitz, F. 2008. The effectiveness and efficiency of public spending. Economic papers. 2008(301). doi: $10.2765 / 22776$.

Miller, T., \& Kim, A. B. (2018). Economic freedom: Policies for prosperity. 2018 Index of Economic Freedom, 9-15.

Mura, L., Daňová, M., Vavrek, R., \& Dubravská, M. (2017). Economic freedom-classification of its level and impact on the economic security. Ad alta: journal of interdisciplinary research, 7(2).

Nikolaev, B. \& Bennett, D. L. (2016). Factor endowments, the rule of law and structural inequality. Journal of Institutional Economics, 12(4), 773-795.

Al-Refai, H., Alawneh, A.,, \& Batiha, K. (2013). Measuring user satisfaction from e-Government services: Lessons from Jordan. Government Information Quarterly, 30(3), 277-288.

Razmi, M. J., \& Refaei, R. (2013). The effect of trade openness and economic freedom on economic growth: the case of Middle East and East Asian countries. International Journal of Economics and Financial Issues, 3(2), 376.

Rodrik, D., Subramanian, A., \& Trebbi, F. (2004). Institutions rule: the primacy of institutions over geography and integration in economic development. Journal of economic growth, 9(2), 131-165.

Sturm, J. E., \& De Haan, J. (2001). How robust is the relationship between economic freedom and economic growth?. Applied Economics, 33(7), 839-844.

Vega-Gordillo, M., \& Alvarez-Arce, J. L. (2003). Economic growth and freedom: a causality study. Cato J., 23, 199.

Weede, E. (2006). Economic freedom and development: new calculations and interpretations. Cato J., 26, 511. 